Pege 1 of 2

\begin{tabular}{|c|c|c|c|c|c|c|}
\hline \multirow{3}{*}{$\begin{array}{l}\text { 2. ECN Category } \\
\text { (mark one) } \\
\text { Supplemental } \\
\text { Direct: Revision } \\
\text { Change ECN } \\
\text { Temporary } \\
\text { Standby } \\
\text { Supersedure } \\
\text { Cancel./Noid }\end{array}$} & \multirow{3}{*}{$\begin{array}{r}{[]} \\
{[x]} \\
{[]} \\
{[]} \\
{[]} \\
{[]} \\
{[]}\end{array}$} & \multicolumn{2}{|c|}{$\begin{array}{l}\text { 3. Originator's Name, Organization, MSIN, } \\
\text { and Tetephone No. } \\
\text { TR Pauly/8KA10/X3-85/372-2438 }\end{array}$} & \multicolumn{2}{|c|}{ 3a. USO Required? } & $\begin{array}{l}\text { 4. Date } \\
11 \text { July } 96\end{array}$ \\
\hline & & \multicolumn{2}{|c|}{$\begin{array}{l}\text { 5. Project Title/No./Work Order No. } \\
\text { K Basins Integrated Water } \\
\text { Treatment Systems/A. } 9\end{array}$} & \multicolumn{2}{|c|}{$\begin{array}{l}\text { 6. Bldg./Sys./Fac. No. } \\
\text { 105KE/105KW }\end{array}$} & $\begin{array}{c}\text { 7. Approval Designator } \\
\text { na }\end{array}$ \\
\hline & & \multicolumn{2}{|c|}{$\begin{array}{l}\text { 8. Document Numbers Changed by this ECN } \\
\text { (includes sheet no and rev.) } \\
\text { WHC-SD-SNF-003, ReV. } 0\end{array}$} & \multicolumn{2}{|c|}{ 9. Related ECH No(s). } & 10. Related PO No. \\
\hline \multirow{2}{*}{\multicolumn{2}{|c|}{$\begin{array}{l}\text { 11a. Modification Work } \\
\text { [] Yes (fill out Btk. } \\
\text { 11b) } \\
\text { X No (NA Blks. 11b, } \\
11 c, 11 \mathrm{~d} \text { ) }\end{array}$}} & \multirow[t]{2}{*}{$\begin{array}{l}\text { 11b. Work Package } \\
\text { No. } \\
\text { N/A }\end{array}$} & \multicolumn{2}{|c|}{ 11c. Modification Work Complete } & \multicolumn{2}{|c|}{$\begin{array}{l}\text { 11d. Restored to Original Condi- } \\
\text { tion (Temp. or Standby ECN onty) } \\
\qquad N / A\end{array}$} \\
\hline & & & \multicolumn{2}{|c|}{ Cog. Engineer Signature \& Date } & \multicolumn{2}{|c|}{ Cog. Engineer Signature \& Date } \\
\hline
\end{tabular}

12. Description of Change

This ECN revises the Statement of Work for Definitive Design of the $K$ Basins Integrated Water Treatment System to reflect the fact that the scope of work described in Rev. 0 of the SOW has been split into two phases, Preliminary Design and Definitive Design, and the fact that Preliminary Design will be completed prior to starting Definitive Design. This change affected the scope of Definitive Design, and the schedule for accomplishing that work. The new scope and schedule for Definitive Design are described in the revised SOW.

13a. Justification (mark one)

Criteria Change $[X]$ Design Improvement As - Found [] facilitate const

[] Enviromental [] Const. Error/Omission

[] []
Facility Deactivation Design Error/onission

13b. Justification Details

It was necessary to split design into two phases, Preliminary and Definitive. The Preliminary phase was used to update the Conceptual Design by incorporating Value Engineering recommendations prior to initiating Definitive Design. This changed the scope and schedule of the original Definitive Design SOW.

14. Distribution (include name, MSIN, and no. of copies)

See attached Distribution Page

A-7900-013-2 (11/94) GEF095 


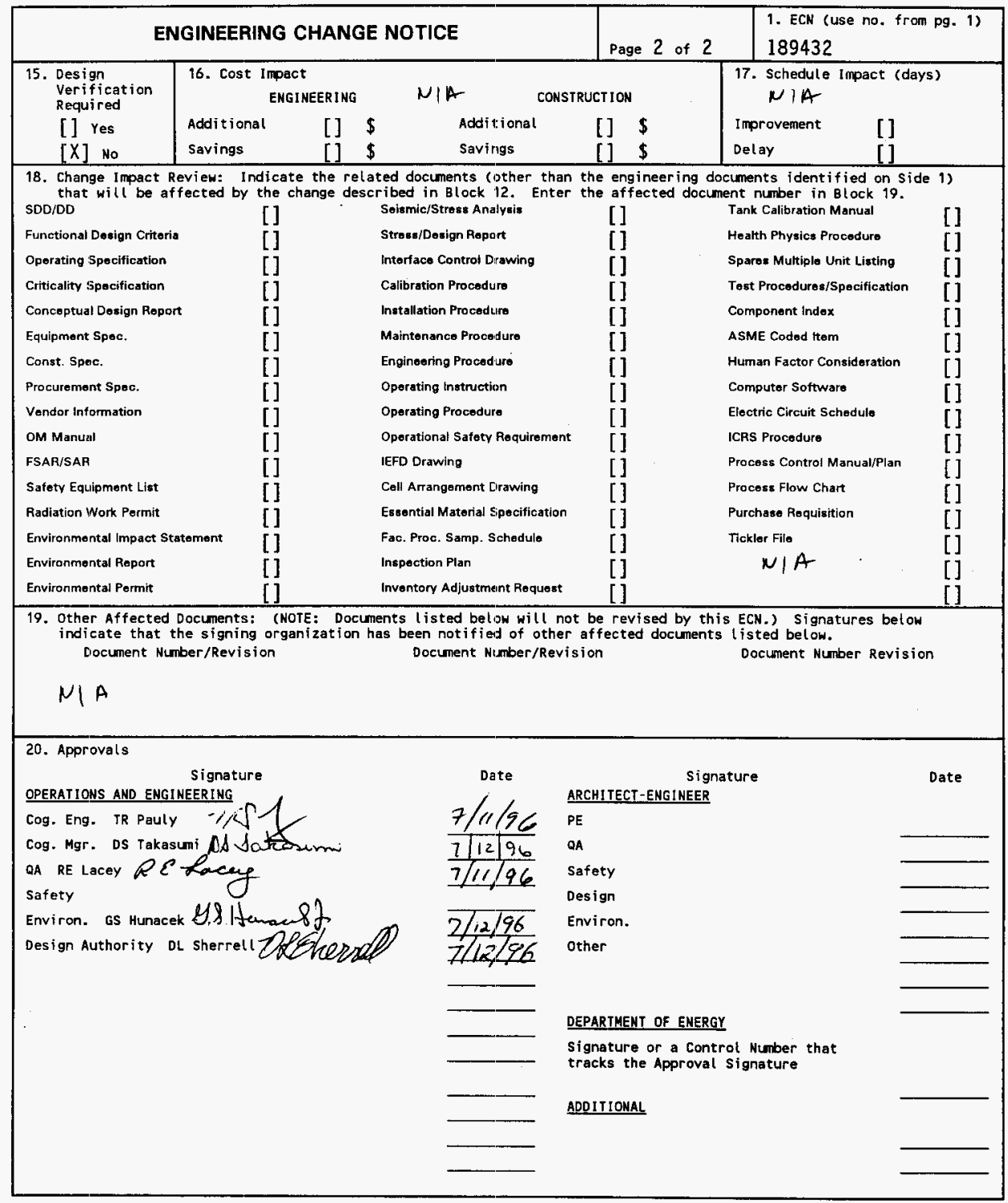




\section{STATEMENT of WORK for DEFINITIVE DESIGN of the $K$ BASINS INTEGRATED WATER TREATMENT SYSTEM PROJECT}

T.R. Pauly

Westinghouse Hanford Company, Richland, WA 99352

U.S. Department of Energy Contract DE-AC06-87RL10930

EDT/ECN: 189432

UC: 602

Org Code: 2A900

Charge Code: LD129

B\&R Code: EW3135040

Total Pages: 23

Key Words: K Basins, Integrated Water Treatment, SOW

Abstract:

This Statement of Work (SOW) identifies the scope of work and schedule requirements for completing Definitive Design of the $\mathrm{K}$ Basins Integrated Water Treatment Systems (IWTS) Subproject. This SOW shall form the contractual basis between WHC and the Design Agent for the Definitive Design.

TRADEMARK DISCLAIMER. Reference herein to any specific commercial product, process, or service by trade name, trademark, manufacturer, or otherwise, does not necessarily constitute or imoly its endorsement, recomendation, or favoring by the United states Goverrment or any agency thereof or its contractors or subcontractors.

Printed in the United States of America. To obtain copies of this document, contact: WHC/BCS Document Control Services, P.D. Box 1970, Malilstop H6-08, Richland WA 99352, Phone (509) 372-2420; Fax (509) 376.4989 .

Oais Braden Relose Approval
7116196

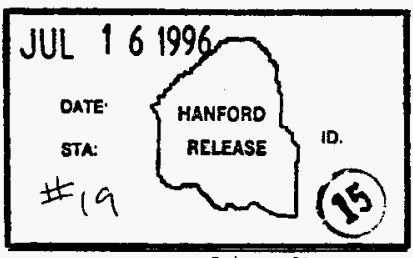

Retease stamp

Approved for Public Release 


\section{RECORD OF REVISION}

(1) Document Number
WHC-SD-SNF-SOW-
003 Reu

(2) Title

Statement of Work for Definitive Design of the $K$ Basins Integrated Water Treatment Project

CHANGE CONTROL RECORD

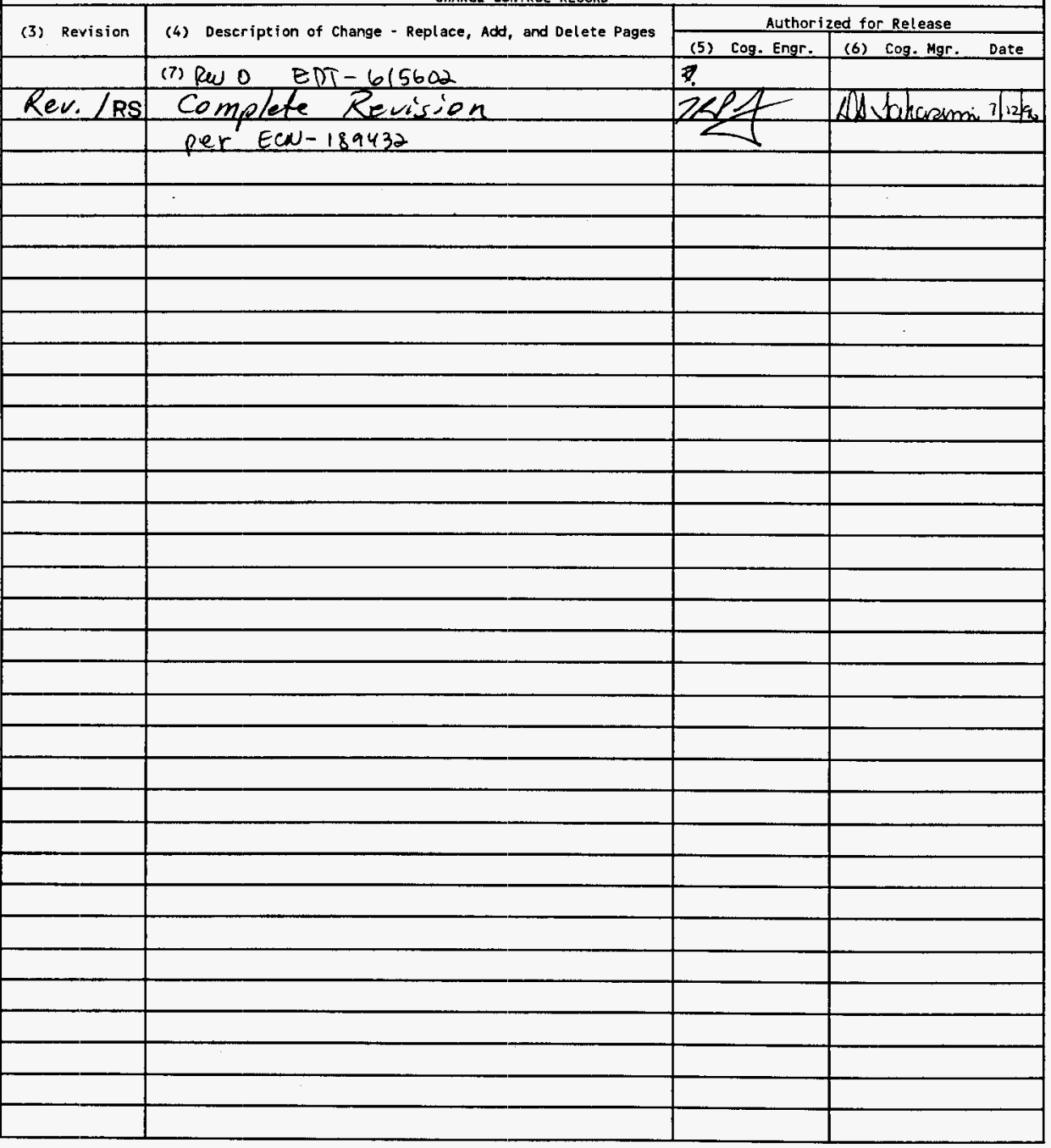




\section{TABLE OF CONTENTS}

1.0 INTRODUCTION .......................... . . . . I

1.1 Background . . . . . . . . . . . . . . . . . . 2

1.2 Location ... . . . . . . . . . . . . . . . . 2

2.0 DESCRIPTION OF REQUIRED SERVICES . . . . . . . . . . . . . . . 3

2.1 Update Preliminary Design Deliverables . . . . . . . . . . 5 5

2.1.1 Definitive Design Work Plan ............. 5

2.1.2 Definitive Design Procedures ............. 6

2.2 Operation \& Maintenance Philosophy \& Assessment . . . . . . 7

2.3 System Design Descriptions . . . . . . . . . . . . . . 7

2.4 ALARA Implementation \& Shielding Analysis Plan . . . . . . . . 7

2.5 Criticality Safety Evaluation Report . ... . . . . . . . . . 7

2.6 Safety Bases ........ . . . . . . . . . . . . 7

2.7 Engineering Drawings . . . . . . . . . . . . . . . 8

2.8 Construction \& Procurement Specifications . . . . . . . . 8

2.9 Acceptance Test Procedures . . . . . . . . . . . . . . 8

2.10 Lists.................... . . 8

2.11 Project Cost Estimate . . . . . . . . . . . . . 8

2.12 Project Schedule .. . . . . . . . . . . . . . . . . 9

2.13 Definitive Design Report ................. . . 9

2.14 0ther Assistance .. . . . . . . . . . . . . . 9

3.0 PROJECT MANAGEMENT . . . . . . . . . . . . . . . . . . . . 10

3.1 Performance of Work . . . . . . . . . . . . . . . . 11

3.2 Technical Approach .. . . . . . . . . . . . . . . 11

3.3 Issues/Concerns and Action Tracking System . . . . . . . . . 12

3.4 Design-to-Cost ................ 12

4.0 MANAgEMENT \& CONTROL . . . . . . . . . . . . . . . 12

4.1 Contractor Work Breakdown Structure . . . . . . . . . . . 12

4.2 Status Reports .................... 13

4.3 Design Reviews .................. 13

5.0 MEETINGS ........................... . . . 14

5.1 Kick-off Meetings . . . . . . . . . . . . . . . . 14

5.2 Progress Meetings .. . . . . . . . . . . . . . . 14

5.3 Design Review Meetings ................. 14

5.4 Working Meetings .................... . . 14

6.0 DOCUMENTS . . . . . . . . . . . . . . . . . . . 15

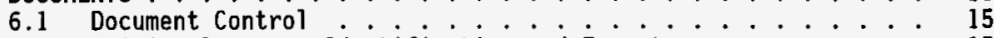

6.1.1 Document Identification and Format . . . . . . 15

6.1.2 Document Approva1 ................ 16

6.1.3 Document Transmittal . . . . . . . . . . . . 16

6.2 Document Files and Objective Evidence . . . . . . . . . . 16

6.3 Drawings ............................. 17 
7.0 DESIGN END ITEMS $\ldots \ldots \ldots \ldots \ldots$

8.0 REFERENCES ...................... 19

9.0 ABBREVIATIONS AND ACRONYMS .................. 19

\section{LIST OF TABLES}

Table 1 Definitive Design Schedule ............. 4

Table 2 Definitive Design End Item Review and Approval Matrix.... 18 


\section{STATEMENT OF WORK FOR DEFINITIVE DESIGN OF THE K BASINS INTEGRATED WATER TREATMENT SYSTEMS PROJECT}

\subsection{INTRODUCTION}

This Statement of Work (SOW) describes the work scope to be performed by the Design Agent under the direction of the Hanford Site operating contractor (OC), currently Westinghouse Hanford Company (WHC), for the preparation of the Definitive Design (Title 2) media for the $K$ Basins Integrated Water Treatment Systems (IWTS) Subproject. The IWTS Subproject consists of the equipment, hardware, facilities, and support systems necessary to maintain water quality, radionuclide levels, clarity, and cooling, during the retrieval, processing, and removal of fuel, debris, and sludge from $K$ East and $K$ West Basins. The Design Agent will be requested to provide reports, studies, analyses, engineering, drawings, estimates, and schedules. The overall goal of this task is to do the following:

1. Using the IWTS Preliminary Design Report as a starting point, this task will provide a Definitive Design Report (DDR) for the IWTS project.

This report will contain a completed design for the planned procurement and construction work consisting of detailed drawings, construction specifications, and acceptance test procedures (ATPS) for construction by the Hanford onsite Engineering \& Construction contractor (EC), or for the bid, award, procurement, construction, installation, testing, and acceptance of work by others. Bid package preparation will be by the EC contractor.

2. Provide a revised project cost estimate and revised project schedule for completing construction of the IWTS.

3. Update as necessary the documents and procedures that will be used during Definitive Design. These will include the IWTS Design Requirements Document, IWTS Quality Assurance Plan, IWTS Configuration Management Plan, and IWTS Design-to-cost Procedure.

4. Achieve project scope within schedule and budget; achieving minimum construction cost consistent with functional, programmatic, environmental, security, and safety requirements.

5. Achieve optimum economy in operations and maintenance with appropriate consideration to expected period of use, sound construction practices, quality assurance requirements, and energy conservation requirements.

6. Selected equipment/systems are designated as government-furnished equipment (GFE) based on compatibility or experiences at the Hanford Site or other government facilities. The Design Agent for definitive design is responsible for integrating GFE items and systems into the overall design. Items identified to date as being GFE include the Ion Exchange Modules (IXMs). 


\subsection{Background}

The Hanford Spent Nuclear Fuel Project has committed to an accelerated schedule for removing spent nuclear fuel (SNF) from the $K$ Basins to a new storage facility in the 200 Areas. A key part of this action involves retrieval of the canisters and fuel rods, decapping of the sealed canisters (KW only), cleaning and inspection of the fuel rods, and transfer into Multiple Canister Overpacks (MCO) for removal from the basins. These activities will stir up and resuspend particulates from sludge on the bottoms of the basins, and decapping of canisters and cleaning of the fuel will release soluble and particulate contaminants (both radioactive and nonradioactive) into the water.

Ouring these activities, it is essential to maintain good visibility in the water, to minimize radionuclide levels in the water, to maintain heat removal for the water, as well as to maintain quality of the water (i.e. maintain water as de-ionized) to minimize further corrosion and dissolution of the fuel elements. The fuel, debris, and sludge retrieval and processing activities will provide increased demands on the existing water treatment systems that will exceed their capabilities for removal of soluble and insoluble contaminants. Also, the new equipment installed in the basins for fue] processing might increase the amount of heat that must be removed to minimize fuel corrosion and algae growth. Therefore, this project will augment and/or replace the existing water treatment systems in KE and KW basin to meet these increased demands.

\subsection{Location}

The K Basins Integrated Water Treatment Systems will be located in the immediate vicinity of 105-KE and $105-\mathrm{KW}$, in the $100 \mathrm{~K}$ area of Hanford. 


\subsection{DESCRIPTION OF REQUIRED SERVICES}

The Seller is the fully-responsible design agent for translating IWTS subproject requirements into a cost-effective design in sufficient detail to facilitate construction of the KE and KW Integrated Water Treatment systems. The principal objective of Definitive Design is to develop a process design integrating GFE, build-to-print systems, and performance specified systems that meets all the IWTS subproject technical baseline design criteria. The IWTS Subproject Technical Baseline consists of two Functional Design Criteria (FDC) documents and S/RIDS:

- WHC-SD-SNF-FDC-002, Functional Design Criteria for the $K$ East Integrated Water Systems (WHC 1996a).

- WHC-SD-SNF-FDC-003, Functional Design Criteria for the $K$ West Integrated Water Systems (WHC 1996b).

- K Basins Standards/Requirements Identification Document (S/RIDS), Rev. 0, WHC-SD-SNF-RD-001 (WHC 1995).

Definitive Design will continue the design effort utilizing the drawings and concepts developed during Preliminary design. As a minimum, the Design Agent is required to perform the activities listed in subsections 2.1 through 2.8 of this SOW. The Design Agent will supplement this activity list by recommending new work items or the upgrade of identified activities, as necessary, to satisfy assessment of the technical baseline. The Design Agent shali accomplish the Definitive Design in accordance with the schedule shown in Table 1. The Design Agent shall submit 10 copies of each interim and final del iverable.

The Design Agent shall be responsible for the quality, technical accuracy, and coordination of designs, drawings, specifications, estimates, and schedules. The tasks will include reports, schedules, estimates, and other special services as specified in this SOW. All design media prepared is the property of the Department of Energy, Richland Operations Office (RL).

The Design Agent shall be responsible for satisfying all safety and health protection requirements imposed on the design by the technical baseline criteria documents, and for developing a defensible safety bases for the project. The Design Agent shall provide all of the technical expertise in different disciplines (i.e., nuclear safety, criticality engineering, fire protection, industrial safety and hygiene, health physics, radiation protection engineering, etc.) as necessary for developing the safety bases. 
Table 1. DEFINITIVE DESIGN SCHEDULE

\begin{tabular}{|c|c|c|}
\hline Item & Sow Sect. & Schedule \\
\hline $\begin{array}{l}\text { Operation and Maintenance Philosophy \& } \\
\text { Assessment Report }\end{array}$ & 2.2 & With in 15 working days \\
\hline System Design Descriptions & 2.3 & Within 20 working days \\
\hline ALARA Implementation/Shielding Analyses $P l$ an & 2.4 & Within 20 working days \\
\hline Criticality Safety Evaluation Report & 2.5 & \\
\hline Safety Bases & 2.6 & \\
\hline Engineering Drawings & 2.7 & \multirow{3}{*}{$\begin{array}{l}\text { Design Reviews for individual } \\
\text { design media will be } \\
\text { specifically identified in } \\
\text { Definitive Design Work Plan } \\
\text { schedule }\end{array}$} \\
\hline Construction \& Procurement Specifications & 2.8 & \\
\hline Lists & 2.9 & \\
\hline Monthly Status Reports & 5.1 & 10th of each month \\
\hline Kick-off Meeting & 6.1 & Within 5 working days \\
\hline Progress Meetings & 6.2 & On or about loth working day of month \\
\hline Definitive Design Report & 2.12 & December 31,1996 \\
\hline
\end{tabular}




\subsection{Update Preliminary Design Deliverables}

During Definitive Design, the Design Agent shall utilize and update as necessary the Preliminary Design deliverables described in the following subsections, which were originally performed under WHC 1996d.

\subsubsection{Definitive Design Work Plan}

The Design Agent shall utilize and update as necessary the work plan for completing Definitive Design. The Definitive Design Work Plan shall identify task objectives, approach, activities, deliverables, schedule, and resources required to accomplish each required work scope item, plus any other supplementary work activities or deliverables recommended by the Design Agent. The work plan shall be accompanied by a corresponding schedule showing durations and logic links for accomplishing the tasks described in the work plan. The work plan information should be presented in a manner consistent with the activity-based Contractor Work Breakdown Structure (CWBS) as described in Section 4.0 of this Sow. The Definitive Design work plan shall, as a minimum, include the following:

- Identify the objective, technical approach, organizational structure, and assigned lead individuals.

- Provide a WBS Dictionary that describes the scope of work and deliverables to be performed for each activity, including all intermediate deliverables such as interim review packages. The WBS Dictionary shall logically roll-up to the CWBS hierarchy.

- Provide an estimate for the quantity and type of resources (e.g. number of labor hours by discipline) required to produce Definitive Design. This estimate shall be derived from and logically tied to the WBS Dictionary.

- Identify key input or outside data needs that must be provided by other subproject participants for each activity. Provide a description of the required input and its restraints on specific activities.

- Identify Definitive Design deliverables that could be logically separated and accelerated to support potential early procurement or early construction activities.

- Provide a schedule that shows the sequence and durations of planned activities, constraints, and interdependence for a 11 activities and milestones. This schedule shall be developed in sufficient detail to plan and control the required work activities. The schedule shall:

- Be a time-phased, resource-loaded, logic-based, critical path network schedule of all design activities

- Indicate definitive design milestones

- Include lower-level schedules as necessary to identify all del iverables.

- Indicate key external input points 


\subsubsection{Definitive Design Procedures}

The Design Agent shall utilize and update as necessary the following procedures that were prepared during the Preliminary Design Phase:

- Project Design Requirements Document (DRD) summarizing all of the criteria, interfaces, and requirements pertinent to this project. The DRD shall evaluate the identified requirements to determine their applicability, identify those criteria areas that require further clarification, and identify potential interpretations or waivers of requirements that are reasonable and would produce cost-effective results. The DRD should further decompose the requirements from the FDC in a disciplined systems engineering approach to the extent that the technical requirements and basic design criteria are clearly defined and traceable throughout the design, acquisition, construction, and operation phases of the IWTS. Refer to the SNF Systems Engineering Management PIan, WHCSD-SNF-SEMP-001, for guidance and use as appropriate.

- Configuration Management Plan - Any deviation from established technical, cost, or schedule baseline is considered a change, as described in the IWTS Project Management Plan, "K Basins Integrated Water Treatment Systems Project Management Plan," WHCSD-SNF-PMP-014 (WHC 1996a). The OC shall approve and implement all changes to the sub-project cost, schedule, or technical baseline. The Design Agent shall identify the configuration management process for control of the definitive design activities. This process shall be identified in the configuration management plan (CMP) that shall be prepared and submitted to the OC for review and approval. The CMP shall be developed in accordance with the guidelines contained in DOE Order 4700.1, Chapter III, Part C.

- Quality Assurance Plan - The Design Agent shall submit, forwHC approva1, a project-specific QAP that provides a description of the intended $Q A$ Program and how the $Q A$ requirements will be applied to the IWTS Subproject. The QAP shall include a matrix of implementing procedures. This matrix shall be developed to demonstrate that each of the applicable requirements of 10CFR830.120 have been addressed in the Design Agent's QAP and implementing procedures. The QAP will be under change control with the $O C$, and will be updated as necessary to address requirements that have been changed, added, or deleted. Design-to-Cost Procedure - The Design Agent is responsible for determining and maintaining current the Total Estimated Cost (TEC) for project construction. As such, the design agent is responsible for providing timely notification to the $O C$ of any favorable or unfavorable trends against the baseline TEC that may occur during design. The Design-to-Cost Procedure shal1 describe how the Design Agent intends to implement a design-to-cost program during definitive design. 


\subsection{Operation and Maintenance Philosophy Assessment}

Pirepare an operation and maintenance philosophy report that clearly explains design assumptions and guidelines. Perform any necessary cost/benefit assessment to select between alternate philosophies.

\subsection{System Design Descriptions}

Prepare System Design Descriptions (SDDs) for the Integrated Water Treatment systems. The SDDs shall describe the system configuration, arrangement, components, interfaces, performance characteristics, operations, maintenance, and safety \& shielding provisions.

\subsection{ALARA Implementation and Shielding Analysis Plan}

Prepare an ALARA implementation plan, perform required shielding analyses, and issue a topical report that describes findings and future work items. To ensure that standardized, validated methods are followed for shielding calculations, WHC will review and concur with the Design Agent's shielding design code(s). In addition, WHC will review and concur with source terms, bases for assumptions, and modeling done in support of shielding design to ensure codes are properly applied and that the principles of "as low as reasonably achievable" have been achieved. Shielding calculations may be reviewed by WHC before the Design Agent uses the calculated values in design.

\subsection{Criticality Safety Evaluation Report}

The Design Agent will be responsible for ensuring that the design meets criticality prevention requirements. A description of how the design meets these requirements, including all bases, calculations, and assumptions, shall be provided in a criticality evaluation report.

\subsection{Safety Bases}

The Design Agent shal1 be responsible for developing the safety bases for the Integrated Water Treatment system so that it may be incorporated into the $K$ Basins Safety Analyses Report (SAR) by the OC. The safety bases shall include identification of Hazard Category, and identification and justification for designation of all Safety Class and Safety Significant structures, systems, and components. The Safety Bases shall identify postulated accident scenarios, assess the consequences of those accidents, and assess the adequacy of proposed barriers for the prevention of the accident or mitigation of consequences. The Safety Bases shall ensure that the Integrated Water Treatment systems can be constructed, operated, maintained, shut down, and decommissioned safely and in compliance with applicable laws and regulations. As part of the safety bases development, the Design Agent shall conduct a Hazards and Operability (HAZOP) review of the design. The OC will review the safety bases for consistency with the $K$ Basins SAR, and will have responsibility for consolidating the safety bases into the $K$ Basins SAR. 


\subsection{Engineering Drawings}

Prepare all engineering drawings including Engineering Change Notices (ECNs) to existing facility drawings necessary for procurement, installation, and construction of the IWTS. Engineering drawings include Piping \& Instrumentation Drawings (P\&IDs), HVAC drawings, General Arrangement Drawings (GAs), Layout Drawings, Electrical one-lines and wiring diagrams, Piping drawings, Build-to-Print drawings, and installation drawings.

\section{8 Construction \& Procurement Specifications}

Prepare all necessary engineering drawings including Piping \& Instrumentation Drawings (P\&IDs), General Arrangement Drawings (GAs), Layout Drawings, and Build-to-Print drawings for the Definitive Design. Separate specification packages may be prepared for $\mathrm{KW}$ and $\mathrm{KE}$.

\subsection{Acceptance Test Procedures}

Prepare Acceptance Test Procedures (ATPs). The ATPs will be conducted by the supplier, engineer/constructor, or integrating contractor to ensure that equipment fabrication, assembly, installation, and/or construction are in accordance with the design requirements. The ATPs shall describe the steps to be followed, with the date to be recorded, in demonstrating the acceptability of the IWTS new installation.

\subsection{Lists}

Develop drawing, specification, equipment, valve, and instrumentation lists. The equipment list shall identify all Safety Equipment and Safety Significant Equipment, including the safety function of such equipment.

\subsection{Project Cost Estimate}

During Definitive Design, the Design Agent shall revise the Subproject Cost Estimate based on the revised and new design media developed during Definitive Design, in accordance with the Subproject Summary Work Breakdown Structure (PSWBS). The cost estimate shall be prepared using the standard Interactive Estimating (IEST), with summary roll-ups by WBS subelement, CSI Division, and DOE Code of Accounts. The OC will supply the estimates of cost for those WBS subelements and activities provided by the $O C$ and the onsite Engineering and Construction (EC) contractor. The EC may be used to prepare the cost estimate and to provide site-specific factors, but the Design Agent shall be responsible for the accuracy of the cost estimate. 


\subsection{Project Schedule}

During Definitive Design, the Design Agent shall prepare a Schedule for IWTS based on the PSWBS. This schedule shall show all phases of the IWTS Subproject from Definitive Design through the execution of Operability Test Procedures (OTPs). As a minimum, the project schedule shall identify discrete activities, durations, and logical interfaces necessary to successfully manage the work scope identified under each level 8 WBS element identified within the Subproject WBS hierarchy. For the construction and installation phases of the project, the schedule shall show as a minimum, those discrete activities that roll up to each level 9 WBS element.

\subsection{Definitive Design Report}

The Design Agent shall prepare a Definitive Design Report (DDR) summarizing the changes in design from Preliminary Design, and including the items prepared under sections 2.1 through 2.12 of this SOW

\subsection{0ther Assistance}

Provide assistance with briefings and formal presentations as requested. The estimated frequency of presentations is one per month. Assistance shall include generation of briefing material (narratives, cost data, and graphics), participation in portions of the briefing, and responding to actions (via agreement/commitment documentation and meeting minutes) for which the Design Agent is made responsible.

Provide input for the training of construction and operations personnel as requested. 


\subsection{PROJECT MANAGEMENT}

The Hanford OC will provide overall project management for the IWTS Subproject. The $O C$ project manager will have responsibility for determining project priorities, establishing overall project schedules, and for ensuring that project activities are completed within established budgets. The OC Procurement Specialist will have responsibility for administration of the Design Agent contract. The $O C$ project engineer is responsible for conducting the day-to-day business of the project, and will be the designated point-ofcontact between the Design Agent and all other Hanford contractor organizations.

The $O C$ Design Authority has responsibility for defining the project's functional requirements, for determining interface criteria between IWTS and other SNF activities and subprojects, and for verifying that the design provided by the Design Agent has satisfied the established requirements. The $O C$ will be responsible for procuring those items or systems designated as GFE on this project. The $O C$ will also be responsible for preparing job control system (JCS) packages for work involving operating or maintenance personnel, for providing independent safety and quality assurance overview, for integrating the A.9 safety bases into the $K$ Basins SAR, and for assessing readiness of the project for installation and start-up.

The onsite Hanford EC contractor, currently ICF Kaiser Hanford, will be responsible for managing the construction portion of this project. This will include providing and supervising onsite construction forces (CF), and providing construction management (CM) for offsite fixed price (FP) contractors. The portion of this project to be constructed by CF primarily includes those construction activities performed in radiologically contaminated areas. The portion of this project to be constructed by FP contractor(s) primarily includes procurement and construction for those activities performed outside of radiologically contaminated areas. The EC will provide bid package preparation for FP bid solicitation.

The Design Agent will have overall technical responsibility for ensuring that the design provided meets the technical requirements established in the FDCs. This will include integrating GFE into the design, developing the safety bases, providing construction drawings for CF work, and providing drawings and specifications for the FP portion of project construction. Engineering services required from the definitve Design Agent during construction will be solicited and procured separately from this SOW. 


\subsection{Performance of Work}

The task objectives, approach, activities, deliverables, schedule, and resources required to accomplish each required work scope item, identified in Section 2.0 of this SOW, plus any other supplementary work activities or deliverables recommended by the Design Agent, shall be presented in the work plan prepared by the Design Agent. The work plan information should be presented in a manner consistent with the activity-based Contractor Work Breakdown Structure (CWBS) as described in Section 4.0 of this SOW. Updates to the work plan shall be submitted for OC review and approval. The Design Agent shall maintain the approved work plan as a controlled document that is updated to reflect any approved changes in the work scope. The Work Plan shall, as a minimum, contain the following:

- Identify technical approach, organizational structure, and lead individuals.

- Provide a WBS Dictionary that describes the scope of work and deliverables to be performed for each activity, including all intermediate deliverables such as interim review packages. The WBS Dictionary shall logically roll-up to the CWBS hierarchy.

- Provide an estimate for the quantity and type of resources (e.g. number of labor hours by discipline) required to produce Definitive Design. This estimate shall be derived from and logically tied to the WBS Dictionary.

- Identify key input or outside data needs that must be provided by other subproject participants for each activity. Provide a description of the required input and its restraints on specific activities.

- Identify Definitive Design deliverables that could be logically separated and accelerated to support potential early procurement or early construction activities.

- Specifically identify the design media that will be reviewed at each planned design review meeting.

- Provide a schedule that shows the sequence and durations of planned activities, constraints, and interdependence for all activities and milestones. This schedule shall be developed in sufficient detail to plan and control the required work activities. This schedule shall clearly show when design reviews are planned.

\subsection{Technical Approach}

The authority to provide technical direction to the Design Agent within the scope of this SOW resides with the OC Project Manager. As such, technical direction will be provided to the Design Agent only by the Project Manager and only by written communication. Any changes to this sow, or direction that impacts the cost/schedule provisions or its terms or conditions, must come only from the procurement specialist. The Design Agent shall notify the $O C$ Project Manager of any direction that impacts the contract provisions and request authorization prior to implementation. 


\subsection{Issues/Concerns and Action Tracking System}

The Design Agent shall maintain an Issues, Concerns, and Action tracking system. This system shall record and track significant design-related issues that are raised by any sub-project participant or outside oversight entity, but are not immediately resolvable. The system shall clearly identify the issue, the party responsible for resolution, and a planned issue closure date. This system shall also record, and track to closure, specific actions requested through correspondence or meetings.

\subsection{Design-to-Cost}

The Design Agent is responsible for determining and maintaining current the Total Estimated Cost (TEC) for subproject construction. As such, the design agent is responsible for providing timely notification to the $O C$ of any favorable or unfavorable trends against the baseline TEC. The definitive design work plan shall describe how the Design Agent intends to implement a design-to-cost program for definitive design.

\subsection{MANAGEMENT and CONTROL}

\subsection{Contractor Work Breakdown Structure}

The Design Agent shall develop a contract work breakdown structure (CWBS) based on the project summary work breakdown structure (PSWBS). The Design Agent's work definitions, budgets, schedules, and cost estimates shall be prepared in accordance with the Design Agent's CWBS. The CWBS shall provide for a logical roll-up of all budget, earned-value, and cost data. The PSWBS is as follows:
1.4 .1 .04 .06 .01 .2
$K$ Basins Integrated Water Treatment Systems
1.4 .1 .04 .06 .01 .2 .1
Project Management
1.4 .1 .04 .06 .01 .2 .2
Definition and Support
1.4 .1 .04 .06 .01 .2 .3
Environmental, Safety and Quality Assurance
1.4 .1 .04 .06 .01 .2 .4
Design
1.4 .1 .04 .06 .01 .2 .5
Procurement
1.4 .1 .04 .06 .01 .2 .6
Construction/Installation
1.4 .1 .04 .06 .01 .2 .7
Start-up 


\subsection{Status Reports}

The Design Agent shall submit a Status Report on or before the tenth day of each month (for the previous month). Each Status Report shall include, but not be limited to, the following information:

- Design Agent's narrative highlights and status assessment for each CWBS reporting element.

- An estimate of the costs for the previous month, and cumulative actual costs for fiscal year-to-date and total task order for each CWBS reporting element.

- Issues or concerns about cost, schedule, and technical baselines with recommended resolution and narrative about any progress towards resolution.

- Agreements or commitments for problems or technical issues resolution.

- Major activities planned before the next monthly status report is due.

- Approved technical baseline change request status.

- Staffing status for planned and actual staff.

- DOE "Cost Performance Report" formats 1 and 3 and Variance Analysis (see DOE Order 1332.1A, Uniform Reporting System [DOE 1985]) completed at the CWBS level. The monthly cost Performance Reports should provide integrated CWBS cost/schedule data for measuring performance. Earned value progress and any changes in the latest revised estimate shall be included in the Cost Performance Report. The Variance Analysis shall be on the current month and cumulative-to-date and include cause, effect, and corrective action. The variance analysis shall be prepared at the CWBS reporting level with explanation lower as required to adequately address problems (offsetting variances, etc.). Cost and schedule variance analysis thresholds (current month and cumulative to date) shall be $\$ 10 \mathrm{k}$ and $10 \%$.

\subsection{Design Reviews}

During Definitive Design, there will be periodic needs to review the design media and provide $O C$ input and concurrence with that media. To minimize impacts to the definitive design schedule, design reviews will be conducted in Design Review meetings as described in Section 5.3 of this SOW. 


\subsection{MEETINGS}

This section of the SOW establishes minimal requirements for formal meetings between the Design Agent and the $O C$. Any informal meetings or oral communications (including telephone conferences) having an impact on the work shall be documented in writing by the Design Agent and provided to the $O C$ Project Manager for concurrence within 3 working days. These communications records shall be issued with a controlled record number and maintained as subproject records.

\subsection{Kick-off Meeting}

A design kick-off meeting will be held at the Design Agent's office after the task is awarded. The purpose of the meeting is to acquaint the Design Agent with the $O C$ personnel assigned or associated with the project. This meeting will focus on a discussion of the SOW and Design Agent's work plan.

\subsection{Progress Meetings}

Progress meetings shall be held at the Design Agent's offices to review progress of the work once per month. During these meetings, the Design Agent shall present technical progress, issues/concerns (cost, schedule, technical), recommended resolution, and progress toward resolution, open issues, actions, and concerns, statused critical path logic network schedules and a forecast of schedule impacts.

During the meetings, the Design Agent shall identify existing or anticipated problem areas for each activity (including impacts), and report on progress toward problem resolution. The Design Agent shall provide an agenda for each meeting at least two working days before the meeting. The Design Agent shall prepare and distribute meeting minutes within 3 working days after the meeting for approval by the OC Project Manager. Minutes shall emphasize issues, concerns, planned actions and responsible individual.

\subsection{Design Review Meetings}

At schedule points specifically identified in the definitive design work plan, design review meetings will be held to provide review and concurrence by the $O C$ and EC with the design media presented at that meeting. The Design Agent. shall prepare and distribute meeting minutes within 3 working days after the meeting for approval by the $O C$ Project Manager. These minutes shall form part of the design review record.

\subsection{Working Meetings}

A routine working meeting shall be held once per week, at a consistent time, place, and day, for the exchange of technical information between the Design Agent, the $O C$, and the EC. The Design Agent shall provide an agenda for each working meeting at least one working day before the meeting. The Design Agent shall prepare and distribute meeting minutes within 3 working days after the meeting for approval by the $O C$ Project Manager. Minutes shall document agreements, issues, and planned resolutions. 


\subsection{DOCUMENTS}

Project documents and contract documents will be generated during the course of the design. Project documents are those end-item documents identified in Section 3.0 and 4.0. Contract documents are those documents identified in the purchase order and this SOW.

\subsection{Document Control}

All topical reports prepared by the Design Agent shall be submitted to the OC for issuance as supporting documents (SDS). The OC shall be responsible for obtaining SD numbers and for releasing SDs; the design agent shall be responsible for submitting topical reports to the $O C$ in $S D$ format.

The Design Agent shall identify in the work plan the records management procedures that establish the controls for collecting, tracking, and maintaining records for the design effort. This procedure shall include receipt, transmittal, processing, disposition, and storage requirements. The Design Agent shall have written procedures in place that delineate the requirements for reviewing, checking, technical editing, and approval of documents before issuance. These procedures shall be issued to the $O C$ for review and concurrence in a document control plan.

\subsubsection{Document Identification and Format}

Numbering system. The Design Agent is required to use a numbering system for all documents, including correspondence, technical reports, and specifications, etc. The numbering system will be developed by the Design Agent and described in the document control plan. Each record document shall show the following:

- Project and contract identification

- SNF K-Basin Integrated Water Treatment Systems Sub-Project A.9

- Contract number/Task Order Number

- Originating firm's name

- End-item document title

- Document identification number (on each page)

- Revision or addendum number or letter (on each page with revised portion indicated)

- Issue or revision date

- Authorized use stamp (e.g., draft, for approval, proprietary information)

- Total number of pages and number of each page (e.g., page 1 of 4)

- Table of Contents or Attachments (as needed)

- Approval signature and title of responsible person in originating firm (released documents only). 


\subsubsection{Document Approval}

All design drawings and technical documents submitted to the $O C$ for review shall first be appropriately reviewed by the Design Agent's technical responsible staff including, but not 1 imited to, QA, safety, and drafting checker personnel. Reports and documents shall be checked for technical and editorial accuracy before they are submitted to the $O C$ for any review. Final design drawings, reports, and documents submitted for acceptance by the $O C$ shall be approved by the Design Agent. Acceptance by the $0 C$ is the act of reviewing a document and acknowledging that it may be used for the purpose intended at that time.

\subsubsection{Document Transmittal}

Unless otherwise agreed upon, transmittal of record documents shall include one reproducible and 10 copies. For documents 1 arger than $81 / 2$ by $11 \mathrm{in}$., photo-quality reproducibles shall be included. Transmittal of record documents produced electronically shall include indices that identify directory and data set file names. Transmittals shall be documented on a suitable, sequentially numbered form that contains a standard document identification number, distribution, and space for reviewers to note the disposition of listed attachments in accordance with the Design Agent's project document transmittal procedure.

\subsection{Record Files and Objective Evidence}

Record files with current and previous revisions shall be maintained for subproject documents in accordance with the Design Agent's approved QA plan. At the conclusion of the task, the OC will advise the Design Agent of the file's disposition. The Design Agent shall keep redundant copies of data needed to meet code or legal requirements.

Objective evidence is test material and unreduced data that support record documents. Objective evidence includes, but is not limited to, material samples used in examinations and tests, instrument records, radiographs, and photographs. Unless needed for evaluation of a non-conformance or other special use, objective evidence will not be distributed. A "record only" transmittal should be issued with the objective evidence listed in the document index and retained with the record files. 


\subsection{Drawings}

A drawing traceability list shall be included near the title block to provide an auditable trail forward and backward between existing and revised drawings. [lrawings shall contain a revision block that includes, at a minimum, a revision number, date of revision, revision description, and revision approval initials. Each drawing shall include a list of interfacing drawings. Final [lesign drawing numbers will be provided by $O C$.

A11 drawings shall be prepared using the computer-aided design and drafting (CADD) process. Any exceptions shall be identified and submitted for approval by the OC. All final engineering drawings will be in compliance with the requirements defined in GG-DWG-01 Preparation and Control Requirements for Engineering Drawings, GG-DWG-02 Autocad Discipl ine Layering Conventions, GGDWG-03 Drawing Index Numbering System, and GG-DWG-04 Parts List/Bi11 of Material. If Design Agent proprietary software is used, the $O C$ shall have free access to it after the design is completed. All commercial software user rights will be transferred to $O C$ on or before the sub-project is completed. Drawings and specifications shall be stamped by a professional engineer $\|$ icensed by the State of Washington.

Full-size drawings shall be $28^{\prime \prime}$ by $40^{\prime \prime}$. Reduced drawings may be $11^{\prime \prime} \times 17^{\prime \prime}$. Reproducible drawings and electronic versions of each drawing shall be furnished by the Design Agent to OC.

\subsection{DESIGN END ITEMS}

End items and approval/concurrence levels for definitive design of the $K$ Basins Integrated Water Treatment Systems are shown in Table 2.

1 Autocad is a trademark of Autodesk, Inc. 
Table 2. Definitive Design End Items Review and Approval Matrix

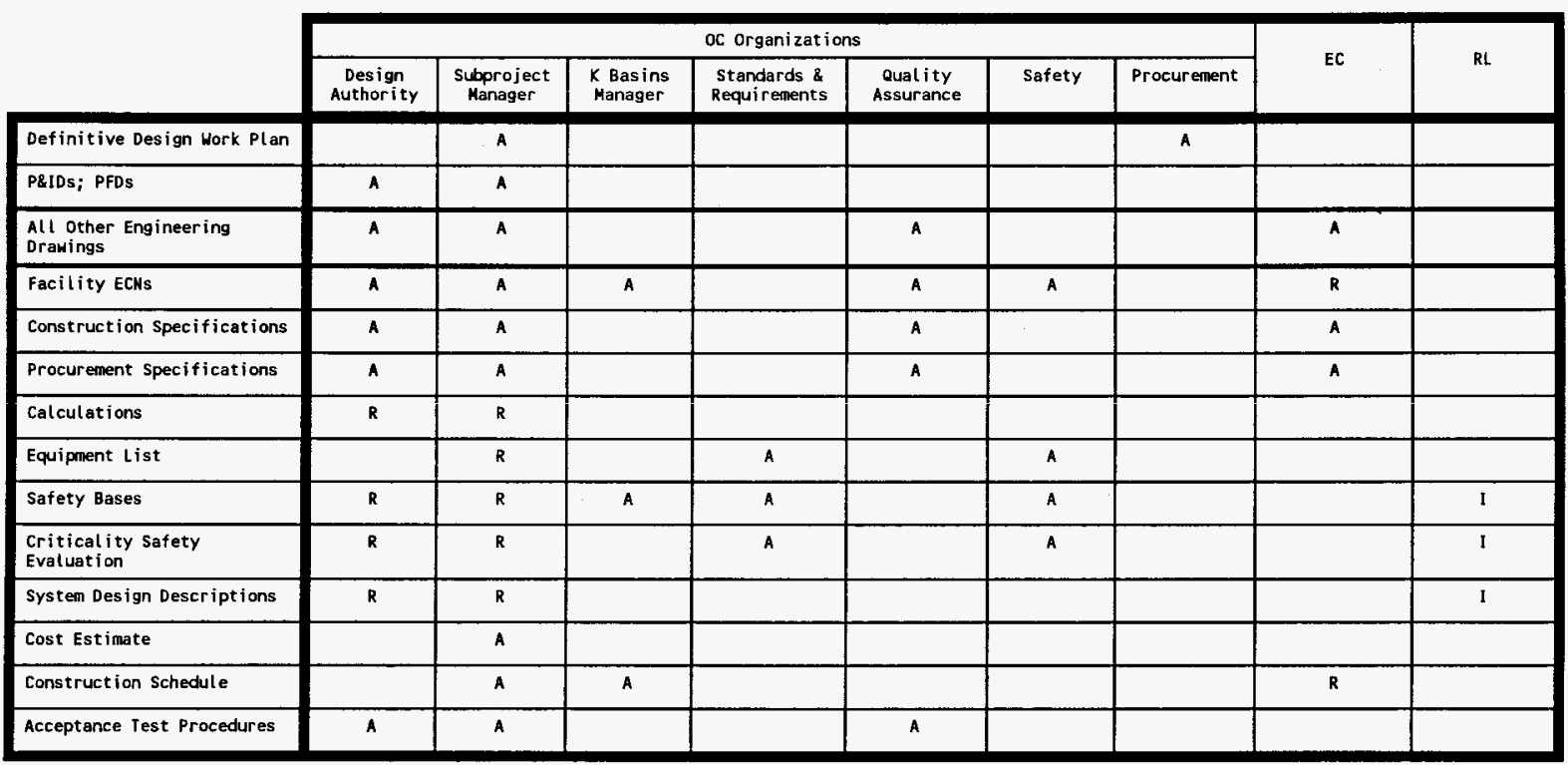

$$
\begin{aligned}
& R=\text { Review } \\
& A=\text { Approve } \\
& I=\text { Information }
\end{aligned}
$$




\subsection{REFERENCES}

WHC 1995, K Basins S/RIDS, WHC-SD-SNF-RD-001, Rev. 0, D.J. Watson, Westinghouse Hanford Company, Richland, Washington.

WHC 1996a, K Basins Integrated Water Treatment Systems Project Management Plan, WHC-SD-SNF-PMP-014, Rev. 0, July 8, 1996, T.R. Pauly, Westinghouse Hanford Company, Richland, Washington

WHC 1996b, Functional Design Criteria for KE Basin Integrated Water Treatment Systems, WHC-SD-SNF-FDC-002, Rev. 0, June 20, 1996, S.A. Brisbin, Westinghouse Hanford Company, Richland, Washington

WHC 1996c, Functional Design Criteria for KW Basin Integrated Water Treatment Systems, WHC-SD-SNF-FDC-003, Rev. 0, July 8, 1996, S.A. Brisbin, Westinghouse Hanford Company, Richland, Washington

WHC 1996d, Statement of Work for Preliminary Design of the $K$ Basin Integrated Water Treatment Systems Project, WHC-SD-SNF-SOW-007, Rev. 0, June 11, 1996, D.C. Derosa, Westinghouse Hanford Company, Richland, Washington

GG-DWG-01, Preparation and Control Requir7ements for Engineering Drawings

GG-DWG-02, Autocad Discipline Layering Conventions

GiG-DWG-03, Drawing Index Numbering System

CiG-DWG-04, Parts List/Bi11 of Material

\subsection{ABBREVIATIONS AND ACRONYMS}

$\begin{array}{ll}\text { ALARA } & \text { As Low As Reasonably Achievable } \\ \text { CADD } & \text { Computer-aided design and drafting } \\ \text { CMP } & \text { Configuration Management Plan } \\ \text { CWBS } & \text { Contractor Work Breakdown Structure } \\ \text { DOE } & \text { U.S. Department of Energy } \\ \text { ORD } & \text { Design Requirements Document } \\ \text { EC } & \text { Engineering \& Construction Contractor } \\ \text { FDC } & \text { Functional Design Criteriat } \\ \text { OC } & \text { Operating Contractor } \\ \text { PSWBS } & \text { Project Summary Work Breakdown Structure } \\ \text { QAP } & \text { Quality Assurance PIan } \\ \text { RL } & \text { U.S. Department of Energy, Richland Operations Office } \\ \text { SEMP } & \text { Systems Engineering Management Plan } \\ \text { SNF } & \text { Spent Nuclear Fuel } \\ \text { SOW } & \text { Statement of Work } \\ \text { WHC } & \text { Westinghouse Hanford Company }\end{array}$




\section{DISTRIBUTION SHEET}

\begin{tabular}{|c|c|c|c|c|c|}
\hline \multirow{2}{*}{$\begin{array}{l}\text { To } \\
\text { Distribution }\end{array}$} & \multirow{2}{*}{\multicolumn{3}{|c|}{$\begin{array}{l}\text { From } \\
\text { K Basins Projects }\end{array}$}} & \multicolumn{2}{|l|}{ Page 1 of 1 . } \\
\hline & & & & \multicolumn{2}{|c|}{ Date $7-11-96$} \\
\hline \multicolumn{4}{|l|}{ Project Title/Work Order } & \multicolumn{2}{|l|}{ EDT No. } \\
\hline \multicolumn{4}{|c|}{$\begin{array}{l}\text { PROJECT A.9 K BASINS INTEGRATED WATER TREATMENT SYSTEMS } \\
\text { STATEMENT OF WORK FOR DEFINITIVE DESIGN, REV. } 1\end{array}$} & \multicolumn{2}{|c|}{ ECN No. 189432} \\
\hline Name & MSIN & $\begin{array}{c}\text { Text } \\
\text { With All } \\
\text { Attach. }\end{array}$ & Text Only & $\begin{array}{l}\text { Attach./ } \\
\text { Appendix } \\
\text { Only }\end{array}$ & $\begin{array}{c}\text { EDT/ECN } \\
\text { Only }\end{array}$ \\
\hline
\end{tabular}

U.S. Department of Energy, Richland 0perations office
E.D. MacAlister
S7 $-41 \quad X$

Los Alamos Technical Associates/British Nuclear Fuels

* D.E. Ball

$$
x 3-85 \quad x
$$

Westinghouse Hanford Company

D.C. Derosa

R.A. Finke

G.S. Hunacek

J.M. Kurta

J.E. Kurtz

R.E. Lacey

T.R. Pauly

D.L. Sherrell

T.S. Smith

D.S. Takasumi

M.J. Wiemers

\section{A.9 Project Files}

* Aduanced copy made

$\begin{array}{ll}\text { X3--85 } & X \\ \text { R2-71 } & X \\ \text { X3-79 } & X \\ \text { X3--74 } & X \\ \text { X3--60 } & X \\ \text { X3--85 } & X \\ \text { X3-85 } & X \\ \text { R3--86 } & X \\ \text { G1 - 25 } & X \\ \text { X3-85 } & X \\ \text { X3-85 } & X \\ \text { X3-85 } & X\end{array}$

$X 3-85 \quad X$ 